\title{
Seasonal Nutrient Content in Food Plants of White-tailed Deer on the South Texas Plains
}

\author{
J.H. EVERITT AND C.L. GONZALEZ
}

\section{Abstract}

From September 1976, through August 1978, 34 white-tailed deer food plants were collected during the months they were eaten by deer on the H.B. Zachry Randado Ranch in south Texas and analyzed for crude protein (CP), $\mathrm{P}, \mathrm{Ca}, \mathrm{K}, \mathrm{Mg}$, and $\mathrm{Na}$. In vitro dry matter digestibility (DMD) was measured on foods collected only during the first year of the study. Mean levels of CP, Ca, K, and $\mathrm{Mg}$ were adequate for deer throughout the year. The $P$ levels were generally inadequate except during spring, whereas $\mathrm{Na}$ levels probably were deficient throughout the year. However, these may not be as deficient as indicated because deer select higher quality plants and plant parts. Crude protein content of browse species was generally higher than that of forbs and cacti. Forbs were generally higher in $\mathrm{P}$ and $\mathrm{Na}$ than were browse and cacti. Although pricklypear cactus generally had low levels of $\mathrm{CP}, \mathrm{P}$, and $\mathrm{Na}$, it had a higher DMD ( $\geq 76 \%$ ) than all other species. However, because of its high soluble ash content $(20 \%)$, pricklypear cactus averaged about $56 \%$ in vitro digestible organic matter. Our data indicated that range managers should provide a diversity of plant species to provide an optimum habitat for deer.

Intensive management of deer requires a thorough understanding of the benefit they derive from each range forage species. Many studies have been conducted on the food habits of white-tailed deer (Odocoileus virginianus) in south Texas (Davis 1951; Davis 1952; Davis and Winkler 1968; Chamrad and Box 1968; Drawe 1968; Everitt and Drawe 1974; Arnold and Drawe 1979). However, deer nutrition was included in only the more recent studies (Varner et al. 1977; Everitt and Gonzalez 1979; Kie et al. 1980). Thus, a more thorough understanding of the nutritive value of important deer foods in south Texas would enhance deer management.

Our objective was to measure the seasonal nutritive value of preferred white-tailed deer foods on the H.B. Zachry Randado Ranch (Zachry Ranch) in the western South Texas Plains. Thirtyfour preferred foods were collected during the seasons they were eaten by deer. The foods were selected for study on the basis of studies on white-tailed deer food habits conducted on the Zachry Ranch by Everitt and Drawe (1974), Arnold (1976), and Arnold and Drawe (1979).

\section{Study Area and Methods}

The Zachry Ranch is about $44 \mathrm{~km}$ southwest of Hebbronville

\footnotetext{
Authors are range scientists, IJ.S. Department of Agriculture, Science and Education Administration, Agricultural Research, Weslaco, Texas 78596.

This study is a contribution from U.S. Dep. Agr., Sci. and Educ. Admin., Agr. Res. Soil and Water Conserv., Res., Weslaco, Texas.

The authors wish to thank personnel of the H.B. Zachry Ranch for thcir help and cooperation in this study. Special thanks is extended to Dr. Mort Kothmann, Department of Range Scicnce, Texas A\& M University, for determining the in vit ro digestible organic matter of pricklypear cactus samples. The authors also acknowledge the help of M.A. Alaniz. and G.V. Latigo, Weslaco, Texas, for their assistance in chemical analyses.

Manuscript received.
}

and $40 \mathrm{~km}$ northeast of Zapata in Jim Hogg and Zapata Countie It is in the South Texas Plains vegetational region (Gould 1975 The ranch has 3,045 ha of rolling brushland intersected by calict hills and gulleys. Eight soil types and six range sites lie within th ranch, but most of the ranch is a sandy loam site comprised McAllen (Aridic Ustochrepts) and Brennan (Aridic Haplustalf fine sandy loam soil types (Higginbotham 1975). The area's clima is mild with short winters and relatively warm temperatur throughout the year. The average length of the growing season 300 days (USDC 1970). Average annual rainfall is $52 \mathrm{~cm}$ an usually occurs in association with thunderstorms that are uneven distributed both geographically and seasonally. Occasionall tropical disturbances produce heavy rainfall, thus September he the highest long term monthly rainfall average with another rair fall peak in May or June from squall-line thunderstorms. $\mathrm{Tr}$ rainfall is lowest in January or February.

The 34 preferred white-tailed deer plant foods studied are liste in Table 1. Samples were collected mid-monthly from Septembe 1976 until August 1978. Each plant species was collected during th months that it is usually eaten by deer on the Zachry Rancl Several plants were collected every month because they were eate throughout the year. The months were grouped by seasons : follows: spring (March-May); summer (June-August); fall (SeI tember-November); winter (December-February). Plant sample were randomly hand-clipped primarily from the sandy loam sit since the major plants were found on this sitc and bccausc this sit comprised most of the ranch. However, samples of the most eate plant species also were collected from some of the minor range site and pooled with those from the sandy loam site for chemic: analyses. Only leaves and the ends of twigs were clipped fror browse plants but both whole plants and leaves were collected fror forb species because deer consumed various parts of these plant Composite samples of 12 or more plants were washed with distille water, air dried at $65^{\circ} \mathrm{C}$, ground in a Wiley mill through a $1-\mathrm{ml}$ mesh screen, thoroughly mixed, and stored in sealed jars.

Plant samples were analyzed for crude protein (CP), $\mathrm{P}, \mathrm{Ca}, \mathrm{M}_{1}$ $\mathrm{K}$, and $\mathrm{Na}$. Total $\mathrm{N}$ was determined by the Kjeldahl method (Peec et al. 1947). Nitrogen levels were multiplied by 6.25 and expresse as percent $\mathrm{CP}$. Levels of $\mathrm{Ca}, \mathrm{Mg}, \mathrm{K}$, and $\mathrm{Na}$ were determined $\mathrm{b}$ atomic absorption spectrometry (Boettner and Grunder 1968 Lanthanum oxide was added to $\mathrm{Ca}$ and $\mathrm{Mg}$ samples to reduc interference. Phosphorus was determined by the rapid digestio method (Bolin and Stramberg 1944). Plant samples were analyze in duplicate, and duplicate results were averaged.

In vitro dry matter digestibility (DMD) was determined by th two-stage technique of Tilley and Terry (1963). Within a week afte collection, duplicate samples of each plant species were treate with rumen inocula obtained from doe deer, killed on the Zachr Ranch. Rumen contents were placed in a prewarmed insulate container and taken to the USDA laboratory at Weslaco, Texas within 2 hours after deer were killed. The DMD percentages wer 
Table 1. Crude protein, phosphorus (P), and dry matter digestibility (DMD) of spring and summer foods of white-tailed deer on the Zachry Ranch in south Texas.

\begin{tabular}{|c|c|c|c|c|c|c|c|c|c|c|c|c|}
\hline & \multicolumn{6}{|c|}{ Spring } & \multicolumn{6}{|c|}{ Summer } \\
\hline & \multicolumn{2}{|c|}{ Crude protein } & \multicolumn{2}{|c|}{$\mathbf{P}$} & \multicolumn{2}{|c|}{ DMD } & \multicolumn{2}{|c|}{ Crude protein } & \multicolumn{2}{|c|}{$\mathbf{P}$} & \multicolumn{2}{|c|}{ DMD } \\
\hline & $\vec{X}$ & S.D. & $\overline{\bar{X}}$ & S.D. & $\vec{X}$ & S.D. & $X$ & S.D. & $\dot{x}$ & S.D. & $X$ & $S . D$. \\
\hline \multicolumn{13}{|l|}{ Browse } \\
\hline Acacia greggii & 21.1 & 3.9 & 0.26 & 0.11 & 53 & 11 & 16.1 & 0.8 & 0.12 & 0.01 & 45 & 5 \\
\hline Bumelia celastrina & 14.1 & 2.9 & 0.19 & 0.08 & 49 & 4 & 13.4 & 1.0 & 0.11 & 0.01 & 50 & 13 \\
\hline Castela texana & 10.9 & .0 .8 & 0.13 & 0.02 & 53 & 4 & 10.4 & 0.5 & 0.10 & 0.01 & 59 & 3 \\
\hline Celtis pallida & 22.4 & 5.2 & 0.25 & 0.08 & 67 & 10 & 20.8 & 2.1 & 0.17 & 0.02 & 67 & 6 \\
\hline Colubrina texensis & 17.8 & 2.5 & 0.25 & 0.08 & 56 & 10 & 15.0 & 3.4 & 0.16 & 0.05 & 49 & 8 \\
\hline Ephedra antisyphlitica & 12.3 & 2.7 & 0.16 & 0.09 & 59 & 2 & 11.9 & 1.8 & 0.13 & 0.04 & 55 & 8 \\
\hline Lantana macropoda & 19.0 & 4.7 & 0.31 & 0.07 & 64 & $\overline{7}$ & 18.9 & 1.5 & 0.26 & 0.04 & 65 & 1 \\
\hline Leucophyllum frutescens & 14.7 & 2.5 & 0.24 & 0.06 & 63 & 13 & 11.6 & 2.9 & 0.16 & 0.03 & 55 & 6 \\
\hline Pithecellobium flexicaule & 23.1 & 3.7 & 0.20 & 0.10 & 57 & 14 & 20.1 & 5.6 & 0.15 & 0.04 & 48 & 3 \\
\hline Porlieria angustifolia & 17.9 & 3.0 & 0.16 & 0.06 & 47 & 5 & 16.6 & 3.3 & 0.08 & 0.02 & 51 & 3 \\
\hline Prosopis glandulosa $a^{I}$ & - & - & 一 & - & - & - & 11.2 & 2.3 & 0.18 & 0.06 & 59 & 2 \\
\hline Schaefferia cuneifolia & 13.6 & 4.5 & 0.20 & 0.09 & 56 & 18 & 12.3 & 4.1 & 0.16 & 0.07 & 52 & 3 \\
\hline Trixis radialis & 20.7 & 2.1 & 0.30 & 0.06 & 58 & 8 & 15.7 & 2.7 & 0.23 & 0.03 & 66 & 3 \\
\hline Zanthoxylum fagara & 17.1 & 4.1 & 0.23 & 0.08 & 63 & 5 & 15.6 & 3.1 & 0.18 & 0.03 & 75 & 3 \\
\hline Ziziphus obtusifolia & 18.5 & 3.7 & 0.26 & 0.10 & 59 & 8 & 14.9 & 1.1 & 0.13 & 0.02 & 52 & 3 \\
\hline Mean & 17.4 & & 0.22 & & 57 & & 15.0 & & 0.15 & & 57 & \\
\hline \multicolumn{13}{|l|}{ Cacti } \\
\hline Opuntia lindheimeri ${ }^{2}$ & 8.5 & 3.6 & 0.17 & 0.07 & 76 & 7 & 6.0 & 1.0 & 0.09 & 0.02 & 76 & 6 \\
\hline Opuntia lindheimeril & - & - & - & - & - & - & 6.2 & 0.6 & 0.15 & 0.04 & 73 & 4 \\
\hline Opuntia leptocaulis & 8.3 & 2.3 & 0.14 & 0.04 & 63 & 10 & 8.0 & 1.2 & 0.14 & 0.03 & 62 & 6 \\
\hline Mean & 8.4 & & 0.16 & 70 & & 6.7 & & 0.13 & & 70 & & \\
\hline \multicolumn{13}{|l|}{ Forbs } \\
\hline Ambrosia psilostachya & 21.4 & 3.4 & 0.37 & 0.05 & 56 & 3 & 16.5 & 3.5 & 0.24 & 0.05 & 60 & 9 \\
\hline Aphanostephus kidderi & 10.0 & 1.2 & 0.27 & 0.04 & 57 & 8 & - & - & - & - & - & - \\
\hline Aphanostephus riddellii & 14.3 & 5.7 & 0.30 & 0.06 & 57 & 4 & 12.6 & 3.1 & 0.21 & 0.06 & 51 & 2 \\
\hline Callirhoe involucrata & 13.1 & 1.8 & 0.31 & 0.06 & 59 & 7 & - & - & - & - & - & - \\
\hline Commelina erecta & $! 3.7$ & 6.4 & 0.24 & 0.06 & 65 & 2 & 17.1 & 3.9 & 0.24 & 0.04 & 62 & 5 \\
\hline Cynanchum barbigerum & 15.4 & 2.2 & 0.24 & 0.06 & 55 & 9 & 13.5 & 2.3 & 0.18 & 0.05 & 61 & 5 \\
\hline Euphorbia prostrata & 16.7 & 4.7 & 0.41 & 0.04 & 53 & 11 & 16.4 & 2.3 & 0.46 & 0.04 & 67 & 4 \\
\hline Gaura brachycarpa & 9.3 & 0.8 & 0.29 & 0.06 & 45 & 15 & - & - & - & - & - & - \\
\hline Lesquerella gracilis & 12.9 & 2.9 & 0.23 & 0.08 & 63 & 6 & - & - & - & - & - & - \\
\hline Lepidium lasiocarpum & 12.7 & 3.4 & 0.24 & 0.07 & 60 & 6 & - & - & - & - & - & - \\
\hline Menodora heterophylla & 14.2 & 1.1 & 0.30 & 0.06 & 67 & 11 & - & - & - & - & - & - \\
\hline Parthenium confertum & 17.8 & 4.9 & 0.29 & 0.06 & 59 & 8 & 17.7 & 6.4 & 0.20 & 0.05 & 58 & 4 \\
\hline Physalis viscosa & 19.7 & 5.6 & 0.24 & 0.07 & 58 & 10 & 15.2 & 1.8 & 0.16 & 0.03 & 67 & 6 \\
\hline Plantago hookeriana & 8.9 & 2.6 & 0.23 & 0.10 & 42 & 15 & - & - & - & - & - & - \\
\hline Psilostrophe gnaphaloides & 13.3 & 5.5 & 0.27 & 0.04 & 50 & 1 & 13.7 & 4.8 & 0.24 & 0.04 & 56 & 2 \\
\hline Verbena plicata & 13.1 & 2.3 & $0.3 !$ & 0.06 & 59 & 2 & - & - & - & - & - & - \\
\hline Xanthisma texanum & 7.9 & 0.4 & 0.25 & 0.07 & 58 & 1 & 8.5 & 1.9 & 0.20 & 0.04 & 52 & 5 \\
\hline Mean & 13.8 & & 0.28 & & 57 & & 14.6 & & 0.24 & & 59 & \\
\hline Overall mean & 15.5 & & 0.26 & & 60 & & 13.9 & & 0.18 & & 59 & \\
\hline
\end{tabular}

'Fruit

${ }^{2}$ Pads

determined only on those samples collected during the first year (September 1976-August 1977) of this study because the ranch manager allowed us to kill a limited number of deer. In vitro digestible organic matter (DOM) expressed as a percent of dry matter was determined on pricklypear cactus pad samples by personnel of the Range Science Department at Texas A\&M University. The DOM was determined on all pricklypear cactus pad samples collected during the 2 years.

We could not statistically compare nutrient quality between years because all species were not available during the same months of both years. Because of a severe freeze in January 1978, some browse species lost their leaves, thus their leaves were not available as food until new growth occurred in March. Also, because of drier conditions in the winter and early spring of 1978, several annual forbs available in March 1977 were not available until April 1978. The mean nutrient content (CP, P, and DMD) and standard deviation was determined for each species during the season it was eaten by deer. Each mean was based on four to six sampling dates. Standard deviations were calculated from within month replicates as well as between month within a season replicates.

\section{Results and Discussion}

The seasonal nutritive content and DMD of major foods of white-tailed deer on the Zachry Ranch in south Texas are shown in Tablcs 1 and 2 and Figure 1. Our data rely heavily on monthly means for all forage classes in the deer diets, as provided by Arnold and Drawe (1979).

\section{Nutritive Value of Spring Foods}

White-tailed deer consumed the greatest number of species in the spring (Everitt and Drawe 1974; Arnold and Drawe 1979). The CP, $P$, and DMD of the spring foods are in Table 1. Crude protein levels ranged from $7.9 \%$ in sleepy daisy (Xanthisma texana) to $23.1 \%$ in Texas ebony (Pithecellobium flexicaule). Nine of the 32 spring foods had less than the minimum protein level of $13 \%$ recommended for maximum gain and reproduction of white-tailed deer (French et al. 1956; Murphy and Coates 1966; Verme and Ullrey 1972). The average CP for all foods was $15.5 \%$. Important spring foods such as catclaw acacia (Acacia greggii), granjeno 


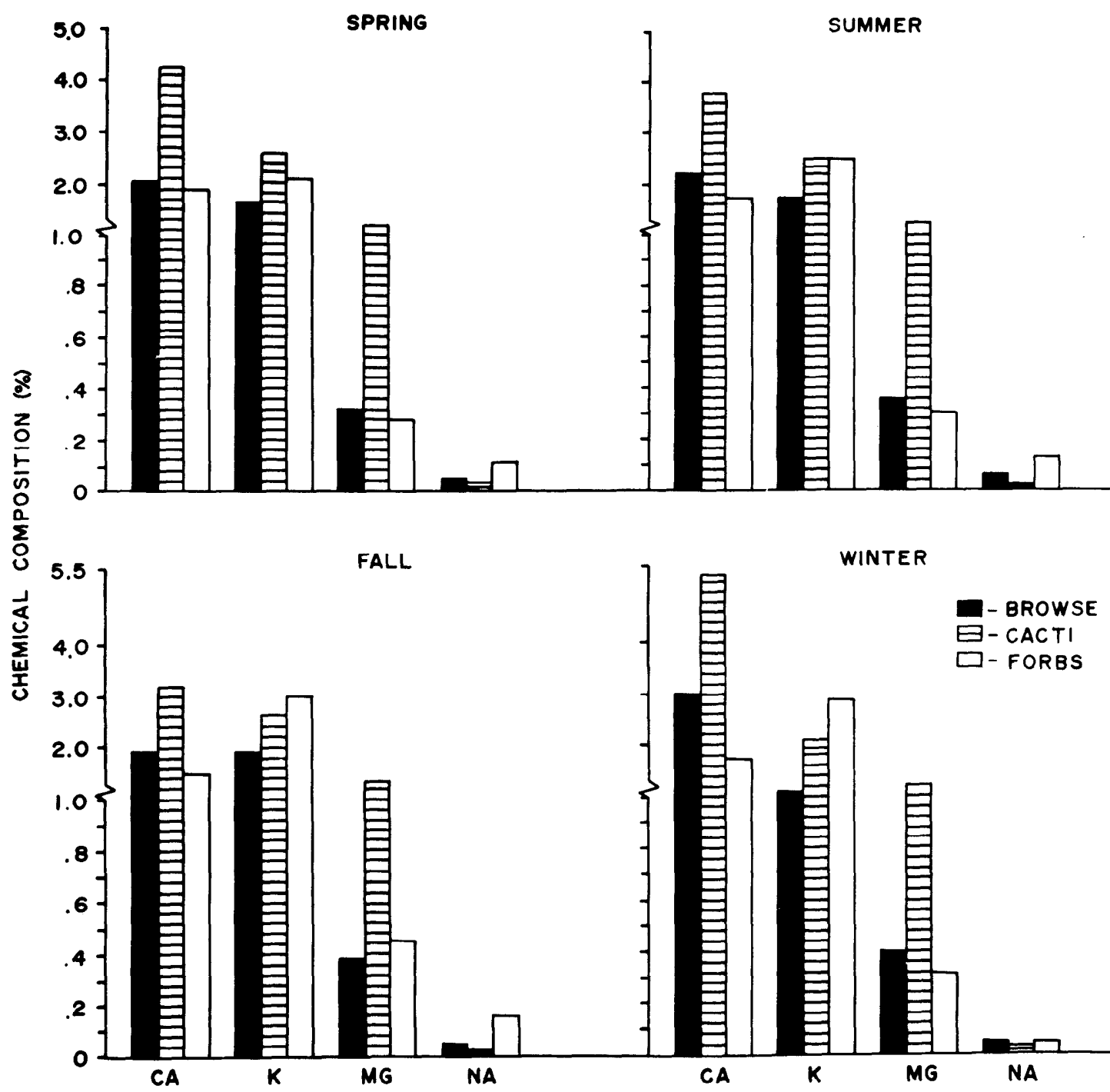

Fig. 1. Mean levels of $\mathrm{Ca}, \mathrm{Mg}, \mathrm{K}$, and Na for browse, cacti, andforbsfor all seasons of the year on the Zachry Ranch in south Texas.

(Celtis pallida), coma (Bumelia celastrina), perennial lazy daisy (Aphanostephus riddellii), groundcherry (Physalis viscosa), and winecup (Callirhoe involucrata) had adequate CP. Crude protein content of browse was generally higher than that of forbs, which agrees with the findings of Varner et al. (1977).

The $P$ requirements of white-tailed deer are not well defined. Magruder et al. (1957) reported that white-tailed deer bucks will survive on rations containing $0.25 \% \mathrm{P}$ but best antler growth was obtained on rations containing $0.56 \% \mathrm{P}$. Based on this standard, the average $P$ level $(0.26 \%)$ of the spring foods was only slightly above the minimum requirement for survival and none of the foods reached the $P$ level considered optimum for antler growth (Table 1). Verme and Ullrey (1972) reported that $0.35 \% P$ was necessary to support optimum growth and antler development of white-tailed deer bucks from weaning to 1 year of age. Even so, prostrate euphorbia (Euphorbia prostrata) and western ragweed (Ambrosia psilostachya) were the only spring foods containing adequate $\mathbf{P}$. Phosphorus levels ranged from $0.13 \%$ in goatbush (Castela texana) to $0.41 \%$ in prostrate euphorbia. Forbs generally had higher levels of $\mathbf{P}$ than browse and cacti, which agrees with other south Texas studies (Varner et al. 1977; Everitt and Gonzalez 1979). The high P content of forbs combined with high forb use in the spring probably raised the dietary $P$ intake of deer (Everitt and Drawe 1974; Arnold and Drawe 1979). Arnold and Drawe (1979) reported that forbs comprised over $50 \%$ of the deer diet from March through May.
Most of the spring foods were high in DMD, from $42 \%$ in tallow weed (Plantago hookeriana) to $76 \%$ in pricklypear cactus (Table 1). The high DMD of forbs, combined with their adequate $C P$ and $P$ content, make these foods important contributors to deer nutrition. Both diet studies conducted on this ranch showed that pricklypear cactus was the most used food (Everitt and Drawe 1974; Arnold and Drawe 1979). Although pricklyper cactus had relatively low levels of CP and P, it had higher DMD than any other plant, and this agrees with the findings of Varner et al. (1977) and Everitt and Gonzalez (1979). However, the high DMD percentage of pricklypear cactus is misleading because of its high soluble ash content (20\%). When expressed as DOM, pricklypear cactus averaged about $56 \%$.

The Ca requirements of deer are probably 0.10 to $0.20 \%$ of the dry ration (Verme and Ullrey 1972). Based on this standard, the $\mathrm{Ca}$ levels of all foods were well above minimum requirements (Fig. 1). $A$ ratio of $\mathrm{Ca}$ to $\mathrm{P}$ of about $2: 1$ is important to insure proper intestinal absorption of these minerals (Maynard and Loosli 1969), but it can be wider if the supply of Vitamin D is adequate (Dukes 1955). By these standards, ratios of $\mathrm{Ca}$ to $\mathrm{P}$ in spring foods were wide, ranging from 4:1 for creeping redbud (Menodora heterophylla) and swallowwort (Cynanchum barbigerum) to 37:1 for tasajillo (Opuntia leptocaulis).

The $\mathrm{K}$ and $\mathrm{Mg}$ requirements of deer are not known. Maynard and Loosli (1969) stated that the minimum $\mathbf{K}$ level needed by ruminants was 0.20 to $0.30 \%$ of the dry ration, whereas the $\mathrm{Mg}$ 
Table 2. Crude protein, phosphorus (P), and dry matter digestibility (DMD) of fall and winter foods of white-tailed deer on the Zachry Ranch in south Texas.

\begin{tabular}{|c|c|c|c|c|c|c|c|c|c|c|c|c|}
\hline \multirow[b]{3}{*}{ Species } & \multicolumn{6}{|c|}{ Fall } & \multicolumn{6}{|c|}{ Winter } \\
\hline & \multicolumn{2}{|c|}{ Crude protein } & \multicolumn{2}{|c|}{$\mathbf{P}$} & \multicolumn{2}{|c|}{ DMD } & \multicolumn{2}{|c|}{ Crude protein } & \multicolumn{2}{|c|}{$\mathbf{P}$} & \multicolumn{2}{|c|}{ DMD } \\
\hline & $X$ & $S . D$. & $X$ & S.D. & $X$ & S.D. & $X$ & S.D. & $x$ & $S . D$. & $x$ & S.D. \\
\hline \multicolumn{13}{|l|}{ Browse } \\
\hline Acacia greggii & 16.0 & 0.5 & 0.13 & 0.01 & 37 & 3 & - & - & - & - & - & - \\
\hline Bumelia celastrina & 13.3 & 0.6 & 0.11 & 0.02 & 44 & 6 & 11.9 & 1.7 & 0.14 & 0.02 & 48 & 8 \\
\hline Castela texana & 11.6 & 0.6 & 0.11 & 0.03 & 59 & 3 & 11.7 & 0.3 & 0.14 & 0.02 & 60 & 2 \\
\hline Celtis pallida & 19.8 & 1.6 & 0.17 & 0.04 & 56 & 1 & 15.2 & 1.5 & 0.14 & 0.02 & 63 & 3 \\
\hline Colubrina texensis & 15.4 & 2.6 & 0.16 & 0.04 & 49 & 6 & - & - & - & - & - & - \\
\hline Ephedra antisyphlitica & 12.9 & 1.7 & 0.14 & 0.04 & 51 & 3 & 11.8 & 1.1 & 0.12 & 0.02 & 48 & 9 \\
\hline Lantana macropoda & 18.9 & 1.5 & 0.27 & 0.03 & 57 & 8 & - & - & - & - & - & - \\
\hline Leucophyllum frutescens & 12.5 & 1.5 & 0.15 & 0.05 & 49 & 4 & 12.5 & 0.9 & 0.17 & 0.03 & 51 & 4 \\
\hline Pithecellobium flexicaule & 22.6 & 1.4 & 0.16 & 0.04 & 45 & 2 & 20.7 & 0.2 & 0.16 & 0.03 & 46 & 2 \\
\hline Porlieria angustifolia & 17.4 & 2.2 & 0.08 & 0.02 & 51 & 2 & 15.0 & 1.3 & 0.10 & 0.03 & 50 & 4 \\
\hline Prosopis glandulosa ${ }^{I}$ & 12.1 & 0.6 & 0.18 & 0.04 & 62 & 4 & - & - & - & - & - & - \\
\hline Schaefferia cuneifolia & 12.5 & 1.3 & 0.16 & 0.06 & 56 & 3 & 10.2 & 1.1 & 0.14 & 0.04 & 54 & 3 \\
\hline Trixis radialis & 17.7 & 2.6 & 0.25 & 0.08 & 61 & 1 & - & - & - & - & - & - \\
\hline Zanthoxylum fagara & 16.6 & 1.6 & 0.20 & 0.03 & 71 & 5 & 15.8 & 1.3 & 0.18 & 0.04 & 70 & 3 \\
\hline Mean & 15.7 & & 0.16 & & 53 & & 13.9 & & 0.14 & & 54 & \\
\hline \multicolumn{13}{|l|}{ Cacti } \\
\hline Opuntia lindheimeri ${ }^{2}$ & 6.6 & 2.2 & 0.09 & 0.02 & 80 & 6 & 6.2 & 1.1 & 0.12 & 0.05 & $7 \dot{8}$ & 3 \\
\hline Opuntia lindheimeril & 8.3 & 1.3 & 0.11 & 0.03 & 58 & 10 & 0.2 & - & - & - & - & - \\
\hline Opuntia leptocaulis & 7.6 & 2.2 & 0.08 & 0.03 & 63 & 2 & 7.5 & 0.9 & 0.11 & 0.03 & 67 & 4 \\
\hline Mean & 7.5 & & 0.09 & & 67 & & 6.9 & & 0.12 & & 73 & \\
\hline \multicolumn{13}{|l|}{ Forbs } \\
\hline Ambrosia psilostachya & 15.1 & 3.6 & 0.24 & 0.03 & 58 & 8 & 18.0 & 7.3 & 0.26 & 0.09 & 57 & 12 \\
\hline Aphanostephus riddellii & 11.6 & 2.4 & 0.19 & 0.04 & 47 & 4 & 14.9 & 2.5 & 0.23 & 0.06 & 49 & 6 \\
\hline Cynanchum barbigerum & 14.3 & 1.6 & 0.18 & 0.03 & 60 & 10 & - & - & - & - & - & - \\
\hline Euphorbia prostrata & 17.6 & 0.7 & 0.38 & 0.08 & 57 & 6 & - & - & - & - & - & - \\
\hline Parthenium confertum & 13.8 & 2.6 & 0.17 & 0.05 & 50 & 8 & 17.2 & 4.1 & 0.23 & 0.06 & 50 & 8 \\
\hline Physalis viscosa & 19.2 & 2.8 & 0.19 & 0.03 & 60 & 8 & 18.4 & 2.9 & 0.21 & 0.05 & 69 & 7 \\
\hline Mean & 15.3 & & 0.23 & & 55 & & 17.1 & & 0.23 & & 56 & \\
\hline Overall mean & 14.5 & & 0.17 & & 56 & & 13.8 & & 0.16 & & 57 & \\
\hline
\end{tabular}

'Fruit

${ }^{2}$ Pads

requirement was only $0.06 \%$ of the dry ration. Based on these standards, all spring foods had adequate amounts of $\mathrm{K}$ and $\mathrm{Mg}$ (Fig. 1).

If the deer $\mathrm{Na}$ requirement is like the 0.10 to $0.20 \%$ reported for pigs and beef cattle (Maynard and Loosli 1969; National Research Council 1970), many of the spring foods were $\mathrm{Na}$ deficient. The generally higher $\mathrm{Na}$ content of forbs makes them an important contributor of dietary $\mathrm{Na}$ (Fig. 1).

\section{Nutritive Value of Summer Foods}

Many foods used in spring also were important during summer; however, most annual forbs had disappeared and the mesquite pods (Prosopis glandulosa) and pricklypear cactus fruit had become available. Although 10 of the 27 foods were deficient in CP for optimum white-tailed deer growth, the average CP level for summer foods was adequate (Table 1). Arnold and Drawe (1979) reported that over $36 \%$ of the summer diet was comprised of pricklypear cactus. Since pricklypear cactus had low levels of CP, deer would be dependent on browse and forbs to supply the dietary protein for optimum growth.

Prostrate euphorbia and desert lantana (Lantana macropoda) were the only species with sufficient $P$ levels for white-tailed deer survival (Table 1). The higher $P$ levels of forbs could offset a serious $P$ deficiency, but forbs usually provide only $10 \%$ of the summer diet of deer (Arnold and Drawe 1979). Thus, $P$ is probably deficient in summer. Most foods were relatively digestible with DMD ranging from $45 \%$ in catclaw acacia to $76 \%$ in pricklypear cactus. Calcium, $\mathrm{K}$, and $\mathrm{Mg}$ levels were adequate in all summer foods (Fig. 1). The Ca:P ratio ranged from 3:1 in prostrate euphorbia to 52:1 in guayacan (Porlieria angustifolia). Forbs only con-

tained Na levels considered adequate for pigs and beef cattle (Fig. 1).

\section{Nutritive Value of Fall and Winter Foods}

The relatively mild cool-season temperature in southern Texas allow several forbs as well as browse and cacti species to remain green during the fall and winter. Mean CP levels of browse and forbs for both the fall and winter were considered optimum for deer growth but CP levels of cacti were below the optimum requirement (Table 2). However, cacti comprised only about $20 \%$ of the fall and winter diet (Arnold and Drawe 1979). Since browse and forbs comprised the major portions of the fall and winter diet, dietary protein levels were probably adequate. The higher level of $\mathrm{CP}$ in forbs during winter was attributed to their succulent winter rosettes. These findings agreed with those of Campbell et al. (1954), Short (1971), and Varner et al. (1977).

With the exception of a few forbs, most fall and winter foods were low in $P$, indicating that $P$ was probably deficient during this period. Most foods had relatively high DMD. Calcium, $\mathrm{K}$, and $\mathrm{Mg}$ were adequate in all fall and winter foods (Fig. 1). The Ca:P ratios were generally wide in all species. With the exception of forbs during the fall, $\mathrm{Na}$ levels were below that considered adequate for pigs and beef cattle (Fig. 1).

\section{Conclusions and Management Implications}

Nutritional data on the 34 preferred deer foods from the Zachry Ranch in south Texas showed that there could be nutrient deficiencies in deer diets. Mean $\mathrm{P}$ levels exceeded the $0.25 \%$ minimum requirement only during the spring season. Other workers have reported $\mathbf{P}$ to be deficient in range livestock forages in south Texas 
and have recommended supplementation (Black et al. 1943; Reynolds et al. 1953). Also, $P$ deficiencies in deer foods are apparently widespread in the United States (Dietz 1965; Blair and Halls 1968; Torgerson and Pfander 1971; Urness et al. 1971; Abell and Gilbert 1974; Short 1977). Although the $\mathrm{Na}$ requirement of deer is unknown, with the exception of forbs, mean levels of other forage classes were never above the $0.10 \%$ minimum requirement of pigs and beef cattle. Providing salt licks on the ranch and the $\mathrm{Na}$ content of well drinking water used by livestock may supplement the $\mathrm{Na}$ intake of deer. However, Weeks and Kirkpatrick (1976) reported that white-tailed deer in Indiana had adapted physiologically, morphologically, and behaviorally to counter Na deficiency.

Our results are indicative rather than definitive. Moreover, sample selection by researchers has often been shown to underestimate the quality of food selected by deer, since deer select the most nutritious plant parts (Klein 1962; Longhurst et al. 1968). Rainfall distribution is irregular in south Texas (USDC 1970). Shortly after high intensity rains, short-lived annual forbs become available. These should provide additional dietary nutrients not accounted for in our samples. Since DMD percentages were obtained only on plant samples collected during the first year, these data might seem inconclusive because of climatic differences between the 2 years (climatic difference resulted in some plants not being available during the same months of both years). However, our DMD percentages agreed with those reported for some of the same plant species in other south Texas studies (Varner et al. 1977; Everitt and Gonzalez 1979). Because the vegetation of the Zachry Ranch is typical of the South Texas Plains, these data should provide an index to the nutritional quality of forage selected by deer in south Texas except during a prolonged period of drought.

Range managers should provide a diversity of plant species if they want a good deer habitat. Although deer use cacti and browse for the major portion of their diet in this area of south Texas, the superior quality of forbs is especially important in meeting their nutritional needs. Common brush manipulation practices, like rootplowing, front-end stacking, or other combinations, increase forb diversity and production especially the first few years after disturbance (Hughes 1966; Gonzalez and Dodd 1979). Thus, opening dense stands of brush by cutting small patches or strips can increase diversity along the edge of the openings, and still leave enough cover and browse on the uncut areas. Domestic livestock numbers should be carefully regulated on these cleared areas so that deer can utilize the increased forb crop.

\section{Literature Cited}

Abell, D.H., and F.F. Gilbert. 1974. Nutrient content of fertilized browse in Maine. J. Wildl. Manage. 38:517-524.

Arnold, L.A., Jr. 1976. Seasonal food habits of white-tailed deer (Odocoileus virginianus Bod.) on the Zachry Ranch in south Texas. M.S. Thesis. Texas A\&I Univ., Kingsville. 59 p.

Arnold, L.A., Jr., and D.L. Drawe. 1979. Seasonal food habits of whitetailed deer in the South Texas Plains. J. Range Manage. 32:175-178.

Black, W.H., L.H. Tash, J.M. Jones, and R.J. Kleberg, Jr. 1943. Effect of phosphorus supplements on cattle grazing on range deficient in this mineral. Dep. Agr. Tech. Bull. 856. 14 p.

Blair, R.M., and L.K. Halls. 1968. Growth and forage quality of four southern browse species. Proc. 21st Annu. Conf. Southeastern Ass. Game and Fish Comm. p. 57-62.

Boettner, E.A., and F.I. Grunder. 1968. Water analyses by atomic absorption and flame emission spectroscopy. In: Trace Inorganics in Water (R.A. Baker, ed.). Adv. in Chem. Serv., Amer. Chem. Soc. 73. 386 p.

Bolin, O.W., and W.E. Stramberg. 1944. Rapid digestion method for determination of phosphorus. Indus. and Engin. Chem. Analyst. Ed. 16:345-346.

Campbell, R.S., E.A. Epps, Jr., C.C. Moreland, J.L. Farr, and F. Bonner. 1954. Nutritive values of native plants on forest range in Central Louisiana. Louisiana State Univ. Agr. Exp. Sta. Bull. 488.18 p.

Chamrad, A.D., and T.W. Box. 1968. Food habits of white-tailed deer in south Texas. J. Range Manage. 21:158-164.

Davis, R.B. 1951. The food habits of white-tailed deer on the cattle stocked, liveoak-mesquite ranges of the King Range, as determined by analysis of deer rumen contents. Unpub. M.S. Thesis. Texas A\&M Univ., College
Station. 97 p.

Davis, R.B. 1952. The use of rumen contents data in a study of deer-cattle competition and "animal equivalence." Trans. N. Amer. Wildl. Conf. 17:448-458.

Davis, R.B., and C.K. Winkler. 1968. Brush vs. cleared range as deer habitat in southern Texas. J. Wildl. Manage. 32:321-329.

Dietz, D.R. 1965. Deer nutrition research in range management. Trans. N Amer. Wildl. and Natur. Resources Conf. 30:274-284.

Drawe, D.L. 1968. Mid-summer diet of deer on the Welder Wildlife Refuge. J. Range Manage. 21:164-166.

Dukes, H.H. 1955. The physiology of domestic animals. 7th ed. Cornell Univ. Press, Ithaca, New York. 1020 p.

Everitt, J.H., and D.L. Drawe. 1974. Spring food habits of white-tailed deer in the South Texas Plains. J. Range Manage. 27:15-20.

Everitt, J.H., and C.L. Gonzalez. 1979. Botanical composition and nutrient content of fall and early winter diets of white-tailed deer in south Texas. The Southwestern Natur. 24:297-310.

French, C.E., L.C. McEwen, N.D. McGrudger, R.H. Ingram, and R.W. Swift. 1956. Nutrient requirements for growth and antler development in the white-tailed deer. J. Wildl. Manage. 20:221-232.

Gonzalez, C.L., and J.D. Dodd. 1979. Production response of native and introduced grasses to mechanical brush manipulation, seeding, and fertilization. J. Range Manage. 32:305-309.

Gould. F.W. 1975. Texas plants -A checklist and ecological summary. Texas Agr. Exp. Sta., Texas A\&M Univ., College Station. MP-585. 121 p.

Higginbotham, I. 1975. Composition and production of vegetation on the Zachry Ranch in the South Texas Plains. Unpub. M.S. Thesis. Texas A\&I Univ., Kingsville. $131 \mathrm{p}$.

Hughes, E.E. 1966. Effects of rootplowing and aerial spraying on microclimate, soil conditions, and vegetation of a mesquite area. Texas Agr. Exp. Sta. Misc. Pub. 812.

Kie, J.G., D.L. Drawe, and G. Scott. 1980. Diet and nutrition of a high density white-tailed deer herd in south Texas. J. Range Manage. 32:2834.

Klein, D.R. 1962. Rumen contents analysis as an index to range quality Trans. N. Amer. Wildl. and Natur. Resources Conf. 27:150-162.

Longhurst, W.M., H.K. Oh, M.G. Jones, and R.E. Kepner. 1968. A basis for the palatability of deer forage plants. Trans. N. Amer. Wildl. and Natur. Resources Conf. 33:181-189.

Magruder, N.D., C.E. French, L.C. McEwen, and R.W. Swift. 1957. Nutritional requirements of white-tailed deer for growth and antler development. II. Experimental Results of the Third Year. Pa. Agr. Exp. Sta. Bull. 628, 21 p.

Maynard, L.A., and J.K. Loosli. 1969. Animal Nutrition. McGraw-Hill, New York, $613 \mathrm{p}$.

Murphy, D.A., and J.A. Coates. 1966. Effects of dietary protein on deer. Trans. N. Amer. Wildl. and Natur. Resources Conf. 31:129-138.

National Research Council Subcommittee on Beef Cattle Nutrition, Committee on Animal Nutrition. 1970. Nutrient requirements of beef cattle. Printing and Publishing Office, Nat. Acad. Sci., Washington, D.C. 55 p.

Peech, M.L., A. Dean, and J.F. Reed. 1947. Methods of soil and analysis for fertility investigations. U.S. Dep. Agr. Circ. 754. 25 p.

Reynolds, E.B., J.M. Jones, J.H. Jones, J.F. Fudge, and R.J. Kleberg, Jr. 1953. Methods of supplying phosphorus to range cattle in south Texas. Tex. Agr. Exp. Sta. Bull. 773. 16 p.

Short, H.L. 1971. Forage digestibility and diet of deer on southern upland range. J. Wildl. Manage. 35:698-706.

Short, H.L. 1977. Food habits of mule deer in a semidesert grass-shrub habitat. J. Range Manage. 30:206-209.

Tilley, J.M.A., and R.A. Terry. 1963. A two-stage technique for the in vitro digestion of forage crops. J. British Grassland Soc. 18:104-111.

Torgerson, O., and W.H. Pfander. 1971. Cellulose digestibility and chemical composition of Missouri deer foods. J. Wildl. Manage. 35:221-231.

United States Department of Commerce. 1970. Climatological Summary. Brownsville, Texas. $46 \mathrm{p}$.

Urness, P.J., W. Green, and R.K. Watkins. 1971. Nutrient intake of deer in Arizona chapparral and desert habitats. J. Wildl. Manage. 35:469-475.

Varner, I.W., L.H. Blankenship, and G.W. Lynch. 1977. Seasonal changes in nutritive value of deer food plants in south Texas. Proc. Annual Conf. S.E. Ass. Fish and Wildlife Agencies. 31:99-106.

Verme, L..J., and D.E. Ullrey. 1972. Feeding and nutrition of deer. In: The Digestive Physiology and Nutrition of Ruminants. Vol. 3. D.C. Church, Ed., Dep. Animal Sci. Oregon State Univ., Corvallis. 350 p.

Weeks, H.P., Jr., and C.M. Kirkpatrick. 1976. Adaptations of white-tailed deer to naturally occurring sodium deficiencies. J. Wildl. Manage. 40:610-625. 